\title{
"Como se liberto nascesse de ventre livre": escravos libertos na Freguesia da Palmeira/PR (1831-1848)
}

\author{
Luís Henrique Novacki ${ }^{1}$
}

\section{Introdução}

Nas últimas décadas do século $\mathrm{XX}$, na maioria dos materiais voltados ao turismo, produzidos pelo estado do Paraná, a cultura paranaense acabou sendo resumida às tradições preservadas pelos imigrantes, que chegaram ao Brasil a partir do final do século XIX. Italianos, alemães, poloneses, ucranianos e japoneses, são considerados como os principais responsáveis pelo 'progresso' do estado, assim como pela conformação de sua cultura.

A repetida veiculação deste pensamento, influenciou decisivamente o imaginário popular, e constitui no que alguns historiadores chamam como "mito do Paraná branco". Ou seja, uma maneira do estado ocultar o fato de que houve em sua história, um período em que a sociedade paranaense foi escravocrata, utilizando o trabalho cativo de indígenas e africanos, principalmente, para sua subsistência. Neste mito, é notório o esquecimento proposital da presença considerável de africanos e seus descendentes nas terras paranaenses, como se os mesmos não fizessem parte, também, da cultura do estado.

Uma das conseqüências desta visão preconceituosa, ao meu modo de ver, pode ser identificada na escassez da produção acadêmica em relação à escravidão no Paraná, ou no que diz respeito a qualquer outro tema relativo aos negros nesta região do país.

Para lembrar à memória coletiva das sociedades, sobre mais este aspecto que compõe a cultura do estado, o presente artigo tem como um dos seus principais objetivos, mostrar ao leitor uma das faces da sociedade escravista paranaense, do início do século XIX. Através das características dos escravos alforriados na Freguesia de Nossa Senhora da Conceição da Palmeira, situada nos Campos Gerais do atual estado do Paraná, entre 1831 e 1848, poderemos fazer algumas considerações sobre as relações entre senhores e escravos nesta localidade.

As fontes primárias utilizadas neste estudo, constituem-se em documentos cartorários pertencentes a esta freguesia. No total foram analisadas trinta e três cartas de alforria, registradas nos Livros de Notas do Escrivão de Paz de Palmeira, no período acima indicado, denominadas nos mesmos como "escripturas de liberdade", e que vieram a libertar quarenta e cinco escravos. Na abordagem destas fontes, o método foi semelhante àquele utilizado pela historiografia, no estudo das alforrias em outras regiões do Brasil, como: Stuart Schwartz e Kátia Mattoso (Salvador/BA), Peter Eisenberg (Campinas/SP) e Adriano Lima (Curitiba/PR).

1 Graduação - História/UFPR (Mestrado - História/UFPR). 


\section{O território paranaense e os Campos Gerais}

A partir de 1765, ano em que ocorre a recuperação da autonomia de governo perdida desde 1748 para a Capitania do Rio de Janeiro, o território da Capitania de São Paulo constitui-se das terras pertencentes aos atuais Estados de São Paulo, Paraná e parte de Santa Catarina*. Com o intuito de facilitar a administração política e militar desta capitania de grande extensão, assim como de outras, o governo português optou por dividi-las em várias comarcas.

Ao longo do tempo, estas comarcas, divididas em várias vilas, tornaramse cada vez mais numerosas. Em 1817 conformavam a Capitania de São Paulo a Comarca de São Paulo, a Comarca de Itú e a Comarca de Paranaguá e Curitiba, que compreendia as terras da futura Província do Paraná, instituída em 1854. Dentre as inúmeras vilas desta última comarca, temos Guaratuba, Paranaguá, Antonina, Cananéia e Iguape localizadas no litoral, e Curitiba, Castro, Vila Nova do Príncipe (atual cidade da Lapa) e Lages. Embora nos primeiros tempos Paranaguá tivesse sido o centro da Comarca, esta posição acabou sendo reivindicada e acatada, após acirrados debates políticos, por Curitiba que passou à condição de principal vila. Como as demais, a vila de Curitiba possuía inúmeras freguesias que estavam sob a sua jurisdição, e que faziam parte do seu termo².

O território que compõe o atual Estado do Paraná foi, até meados do século XIX, uma expansão do núcleo inicial da Província de São Paulo, e por este motivo manteve-se fiel ao "modelo paulista" de utilização da mão-de-obra escrava. Ao longo do século XVII, foram utilizados índios cativos, juridicamente denominados de "administrados". No século XVIII, essa mão-de-obra foi sendo substituída em larga escala por escravos africanos, que seriam concentrados nos locais de maior importância econômica da região. Estes locais correspondem ao litoral, ao planalto curitibano, ou Primeiro Planalto, e aos Campos Gerais ${ }^{3}$.

No início do século XVIII são concedidas, pelo reino português, várias sesmarias nos Campos Gerais, uma região à oeste de Curitiba onde predominam extensas pastagens naturais de gramíneas (ideais para a alimentação do gado) e pequenas matas, próxima ao caminho que ia desta para São Paulo. Nos Campos Gerais, sobressai na paisagem uma espécie de árvore típica do sul do Brasil, que tanto impressionou o botânico francês Auguste de Saint-Hilaire (1779-1853) quando o mesmo esteve no Brasil na década de 1820: a Araucária angustifolia, batizada por este como Araucária brasiliensis. Saint-Hilaire, ressalta ainda que esta árvore possuía uma madeira resistente, além de disponibilizar aos habitantes da região as suas sementes (pinhão), "que sempre alimentou os indígenas". ${ }^{4}$ Nas descrições deste viajante, uma das razões para a fraca presença de escravos na região era

\footnotetext{
* Referir-se ao Paraná, no início do século XIX é, com certeza, um anacronismo. No entanto, é difícil encontrar um termo que designe corretamente a região que hoje configura o Estado. Não posso, inclusive, referir-me à $5^{a}$ Comarca, pois ocorreram alterações na divisão judiciária na capitania de São Paulo durante o período estudado. Assim, optei por utilizar Paraná para não tornar a redação massante, entendendo que o leitor saberá levar em conta esta licença.

2 CASAL, M. A. apud. Corografia brasílica. São Paulo : Edusp; Belo Horizonte : Itatiaia, 1976, p. 106 in: LIMA,

A. B. M. op. cit. p. 17.

3 PEREIRA, M. R. M. op. cit., p.57.

4 SAINT-HILAIRE, A. de. Viagem à Curitiba e Santa Catarina. São Paulo : Editora da USP : Editora Itatiaia, 1978. p. 16.
}

68

Qevista Pernáculo 
que "A criação de gado, a qual se dedica a maior parte da população, exige poucos escravos, ao passo que se torna necessário um grande número deles para o fabrico do açúcar e o trabalho nas Minas." ${ }^{5}$

Os proprietários destas sesmarias, eram homens abastados de Santos, São Paulo e Paranaguá, que utilizaram suas terras como fazendas de criação de gado (bovinos, eqüinos e muares) a fim de abastecer o crescente mercado consumidor, originado com a descoberta das minas de ouro de Minas Gerais, porém sua produção era insuficiente. Como forma de minimizar o problema, o governador de São Paulo mandou abrir a estrada da Laguna em 1728-31, possibilitando a condução de tropas de gado (principalmente mulas, mas também cavalos) do Rio Grande do Sul, para os Campos Gerais e depois para São Paulo, mais precisamente para a Feira de Sorocaba. Nesta feira, o gado seria comercializado e seguiria para as Minas Gerais. Iniciava-se desta forma o período denominado de "tropeirismo"6.

No ciclo das tropas, ou seja, do período da abertura da estrada até o final do século XIX (1870), as fazendas dos Campos Gerais passaram então a realizar a invernagem ou engorda das mulas, enfraquecidas pelos longa viagem (três meses) que iniciava na serra gaúcha, além de continuarem com a criação de bois, cavalos e carneiros, utilizando o trabalho escravo para desenvolver estas atividades. Os carneiros, destinavam-se a produzir a lã utilizada na confecção de ponchos e mantas. Além de Palmeira, outras cidades desta região como Castro, Ponta Grossa, Lapa, formaram-se em decorrência do roteiro das tropas.

Estes ricos sesmeiros que obtinham seus latifúndios por intermédio de uma concessão régia, começaram a edificar suas fazendas às margens do caminho que interligava Curitiba às cidades de Sorocaba e São Paulo, e não se transferiram inteiramente para esta região. Eles encaravam os Campos Gerais como um lucrativo negócio a ser explorado comercialmente, ocupando o local como proprietários absenteístas, ou seja, raramente estavam presentes em suas fazendas, deixando as mesmas sob a responsabilidade de algum agregado de confiança, em alguns casos essa pessoa poderia ser um escravo ${ }^{7}$.

A presença africana na pecuária da região é descrita por quantos por ela passaram. A lida com o gado era feita por escravos e libertos, o que chamava atenção por não ser o padrão corrente no Brasil.

\footnotetext{
"Colocava-se uma rédea no cavalo e este era amarrado a um mourão; sobre o seu lombo era posta uma sela denominada lombilho, e o domador montava nele. Não pude deixar de admirar o sangue-frio e a perfeita calma desse homem. Por mais fogoso que fosse o cavalo, por mais saltos e corcovos que desse, era impossível perceber a mais leve alteração na fisionomia do ne gro domador; quando o animal se atirava ao chão o domador saltava fora com grande agilidade e tornava a montar, sem jamais proferir uma única palavra"».
}

5 Ibid. p. 19.

6 PILATTI BALHANA, A.; PINHEIRO MACHADO, B.; WESTPHALEN, C. História do Paraná, Curitiba : Editora Grafipar, 1968. p.39.

7 Entre os anos de 1725 e 1744, segundo Brasil Pinheiro Machado, mais de noventa (90) sesmarias foram concedidas nesta região. Em 1772 existiam cinqüenta (50) grandes fazendas e cento e vinte e cinco (125) sítios, tendo como eixo a "estrada das tropas" ou o caminho de Viamão.

8 SAINT-HILAIRE, A. de. op. cit. p. 22. Negrito meu. 
Outro ofício desempenhado por africanos nestas fazendas de gado dos Campos Gerais, foi a de capataz. Quando hospedou-se na fazenda Caxambu, do Coronel Luciano Carneiro, o botânico francês foi "servido pelo capataz, que na ausência do dono administrava a fazenda, e que no entanto não passava de um escravo. (...) Era cortês sem ser servil, e embora dirigisse os outros escravos com autoridade (...)"

Ao longo dos séculos XVIII e XIX, a sociedade dos Campos Gerais estava voltada economicamente para a pecuária e para a agricultura de subsistência, sendo formada por diversos grupos sociais. Estes, eram constituídos pelos fazendeiros e sua numerosa família, pelos tropeiros ou peões de tropa, e pelos comerciantes, que tinham suas casas de comércio localizadas nas vilas ou nos "arraiais"10, coexistindo com pequenas propriedades nas quais desenvolvia-se uma agricultura de subsistência. Dentre os tropeiros, temos um número significativo de escravos, que incluem-se na problemática central deste estudo. No entanto, a grande dificuldade na apreensão destes africanos e/ou afro-brasileiros como objeto de análise, ocorre em função da complexidade das atividades desenvolvidas pelos mesmos, assim como das relações mantidas com seus senhores em cada uma delas. O escravo poderia trabalhar tanto no interior da fazenda quanto fora dela, ou seja, quando o mesmo compunha o grupo dos tropeiros, independente da sua hierarquia na tropa.

Uma das fazendas de gado dos Campos Gerais, denominada de Fazenda Palmeira e que pertencia à Manoel José de Araújo (bisavô de Moisés Marcondes), tornou-se local de pousio para os tropeiros que seguiam em direção à Feira de Sorocaba. Seu proprietário decidiu doar uma pequena parte deste latifúndio, certamente próxima à sede da fazenda, entre os anos de 1818 e 1819, para a construção da futura Igreja Matriz, que teria como padroeira Nossa Senhora da Conceição. Esta doação ocorreu em função da única capela da região (Capela de Tamanduá), estar situada um tanto quanto afastada da Fazenda Palmeira, e também por possuir modestas acomodações.

A povoação que estabeleceu-se nas proximidades da futura igreja, inicialmente denominada de Freguesia Nova, passou a ser denominada como Freguesia de Nossa Senhora da Conceição da Palmeira, pertencente ao termo da vila de Curitiba, mesmo antes da conclusão da igreja que ocorreu em 1837. Somente em 1870, quando termina o chamado ciclo das tropas, é que Palmeira ascende à categoria de vila ${ }^{11}$. Nesta freguesia, assim como em várias outras, a disseminação do estatuto da escravidão, no qual o sistema patriarcal baseia-se na relação senhor-escravo, é claramente perceptível através da documentação paranaense. Em qualquer arquivo que mantenha uma documentação referente aos séculos XVIII e XIX, a presença do escravo é uma constante na sociedade em questão.

\section{Negros e mulatos escravizados}

As fontes referentes à demografia da população paranaense no início

9 Ibid. p. 39.

10 PINHEIRO MACHADO, B. Campos Gerais - Estruturas Agrárias, Curitiba : Editora da UFPR, 1968. p.29-30.

11 FREITAS, A. Palmeira. Reminiscências e Tradições, vol. II. Curitiba : Editora Lítero -Técnica, 1984. p. 13-30. 
do século XIX são bastante imprecisas, impossibilitando que o historiador saiba com exatidão qual a quantidade de habitantes de cada cidade, e consequentemente da totalidade do território. Uma estimativa nos revela o quantitativo da população do Paraná em 1822 e sua respectiva condição jurídica, totalizando para este ano 31.566 habitantes, sendo:

\begin{tabular}{|l|c|c|c|}
\hline & LIVRES & ESCRAVOS & ESCR. / COR (\%) \\
\hline Brancos & 17.618 & --- & 0.00 \\
\hline Pardos & 7.615 & 1.811 & 23.78 \\
\hline Pretos & 618 & 3.905 & 86.34 \\
\hline TOTAL & 25.850 & 5.716 & 22.11 \\
\hline
\end{tabular}

* Baseado em PILATTI BAlHANA, A.; WestPhALEN, C. Paraná 1822. Boletim n. ${ }^{\circ} 19$ do Departamento de História da UFPR. Curitiba : Gráfica Vicentina, 1972. P. 15.

De acordo com a tabela acima, podemos constatar que no período referente à Independência do Brasil, 23.78\% dos paranaenses considerados como "pardos" eram escravos. Se considerarmos, como é plausível, que o termo designava os mulatos, chegaremos à conclusão que praticamente a metade da população escrava paranaense era mestiça, brasileira. Estes dados nos mostram que, como em outros locais do país, a proporção entre escravos nascidos na Africa e no Brasil tendeu para um equilíbrio, no início do século XIX. A partir da proibição do tráfico de escravos, em 1831, decresce cada vez mais o número de africanos nas populações.

Outra fonte demográfica a ser considerada é o censo realizado na década de 1850, às vésperas da emancipação da província do Paraná, que totalizou 62.258 habitantes. Embora imperfeito, ele nos dá uma noção mais abrangente no que diz respeito à cor e à condição jurídica dos habitantes:

\begin{tabular}{|l|l|l|l|l|l|l|l|l|}
\hline Cidade & Habit. & Brancos & Pardos & Pretos & Escr. & $\begin{array}{l}\text { EscravosI } \\
\text { Habit. }\end{array}$ & $\begin{array}{l}\text { Não Bran- } \\
\text { cos }\end{array}$ & $\begin{array}{l}\text { Escrav.I N } \\
\text { Branc. }\end{array}$ \\
\hline Paranaguá & 6533 & 4150 & 1109 & 1274 & 1274 & $19.50 \%$ & 2383 & $53.46 \%$ \\
\hline Guaraqueç. & 3476 & $2 \times 46$ & 382 & 248 & 248 & $7.13 \%$ & 6.30 & $39.37 \%$. \\
\hline Guaratuba & 1564 & 736 & 630 & 198 & 175 & $11.19 \%$ & 828 & $21.14 \%$ \\
\hline Antonina & 4160 & 2664 & 604 & 892 & 838 & $20.14 \%$ & 1496 & $56.02 \%$ \\
\hline Morretes & 3709 & 1563 & 1234 & 912 & 755 & $20.36 \%$ & 2146 & $35.18 \%$ \\
\hline Curitiba & 6791 & 4624 & 1293 & 874 & 578 & $8.51 \%$ & 2167 & $26.67 \%$ \\
\hline São José & 4660 & 2696 & 992 & 972 & 365 & $7.83 \%$ & 1964 & $18.58 \%$ \\
\hline C. Largo & 3690 & 2101 & 979 & 610 & 359 & $9.73 \%$ & 1589 & $22.59 \%$ \\
\hline Palmeira & 1818 & 1028 & 427 & 363 & 269 & $14.80 \%$ & 790 & $34.05 \%$ \\
\hline Iguaçu & 1652 & 952 & 629 & 71 & 71 & $4.30 \%$ & 700 & $10.14 \%$ \\
\hline Votuverava & 2018 & 1060 & 815 & 143 & 126 & $6.24 \%$ & 958 & $13.15 \%$ \\
\hline Príncipe & 5406 & ---- & ---- & ---- & 1858 & $34.37 \%$ & --- & $-1 .-$ \\
\hline Rio Negro & 1884 & 868 & 952 & 64 & 77 & $4.09 \%$ & 1016 & $7.58 *$ \\
\hline
\end{tabular}




\begin{tabular}{|l|l|l|l|l|l|l|l|l|}
\hline Castro & 5899 & 3618 & 1295 & 986 & 796 & $13.49 \%$ & 2281 & $34.90 \%$ \\
\hline Pta. Grossa & 3033 & 1889 & 746 & 398 & 1059 & $34.92 \%$ & 1144 & $92.57 \%$ \\
\hline Jaguariaíva & 1071 & 490 & 260 & 321 & 440 & $41.08 \%$ & 581 & $75.73 \%$ \\
\hline Tibagi & 1640 & 801 & 492 & 347 & 354 & $21.59 \%$ & 839 & $42.19 \%$ \\
\hline Guarapuava & 2520 & 1193 & 909 & 418 & 379 & $15.04 \%$ & 1327 & $28.56 \%$ \\
\hline Palmas & 734 & 354 & 220 & 160 & 158 & $21.53 \%$ & 380 & $41.58 \%$ \\
\hline
\end{tabular}

* Fonte: PEREIRA, M. R. M. Semeando iras rumo ao progresso. Curitiba : Editora da UFPR, 1996. p.59. Tabela elaborada a partir de dados obtidos em PARANÁ. Relatório do Presidente Zacarias de Góes e Vasconcelos

Analisando os números acima, podemos concluir que somente a região dos Campos Gerais, onde na primeira metade do século XIX "prevaleciam os latifúndios agropastoris dedicados à pecuária bovina e à invernagem e comércio de muares provenientes do Rio Grande do Sul", pode ser considerada como uma sociedade escravista ou escravocrata ${ }^{12}$. É nítida também a exceção que foi Ponta Grossa, onde quase todas as pessoas consideradas como não pertencentes à raça branca (92\%) eram escravas. Ponta Grossa e a vila do Príncipe (atual Lapa), contabilizavam para cada 100 habitantes 34 escravos. Mesmo fazendo parte desta região, Palmeira não se caracterizava por uma forte presença escrava, pois os dados deste censo nos revelam que nesta freguesia para cada 100 habitantes, aproximadamente 15 eram escravos. Também é notório o fato de que em Palmeira, o número total de habitantes é bem menor que nas outras cidades da região.

No entanto, obter a liberdade através dos trâmites legais, foi uma prática constante escravos paranaenses dos Campos Gerais na primeira metade do século XIX, haja vista o considerável número de cartas de alforria existentes nos Livros de Notas deste período, e que constituem-se nas principais fontes primárias utilizadas nesta análise.

\section{A passagem para outro estatuto jurídico}

Até o final do século XIX, o Brasil foi fortemente marcado pela escravidão, conformando uma sociedade caracterizada pela estratificação social. A posse de escravos, constituía-se numa das maneiras de ascensão social, ou seja, o proprietário mudava de status na sociedade, assumindo a condição de senhor de escravos $^{13}$. Ter um escravo, mesmo que ele fosse uma das únicas propriedades adquiridas, significava estar isento da necessidade de trabalhar, sendo o elemento cativo muitas vezes o responsável pelo sustento de famílias inteiras. E enganamse os que acreditam que este era um desejo apenas do cidadão abastado, branco e livre do meio rural, pois esta ambição estendia-se também aos elementos dos núcleos urbanos: padres, artesãos, funcionários públicos, libertos e até mesmo escravos.

Os escravos eram considerados, juridicamente falando, como indivíduos desprovidos do direito de propriedade sobre qualquer coisa, inclusive sobre a

12 PEREIRA, M. R. M. op. cit., p.58.

13 CALDEIRA, J. et al. Viagem pela História do Brasil. São Paulo : Companhia, das Letras, 1997. p. 154. 
sua liberdade, considerada atualmente, como um dos mais elementares direitos do homem. E diante de tal situação, temos juntamente com escravidão, a convivência da eterna busca pela liberdade.

A passagem da escravidão ao estatuto de liberto, incidia sobre muitos aspectos da vida de uma pessoa, o que pode ser comprovado através das punições previstas nas Posturas Municipais do século XIX. Aqueles que não agissem de acordo com as mesmas recebiam punições diferenciadas, as livres eram punidas através do pagamento de uma multa ou da prisão na cadeia pública da localidade por alguns dias, e os escravos através de açoites em local público.

\begin{abstract}
Capítulo primeiro $=$ Artigo primeiro $=$ Todo indivíduo livre, que for axado com armas de defezas de dia, ou de noite, como faca de ponta, pistollas, bacamartes, e etc. dentro desta Villa, suas Freguezias Capellas, e Arraiaes, perder tais armas com que for apanhado para o Official e seus homens que lhas tirarem, e pagar hua multa pecuniaria de dois mil reis para as dispesas do Concelho ou seis dias de prizão senão tiver de que satisfaça a mencionada multa $=$ Artigo segundo $=0$ Escravo que for axado com ditas armas, alem da perda delias será publicamente castigado com vinte cinco assoites. Capítulo terceiro = Artigo setimo $=$ Todo individuo que para taes ajuntamentos (espetaculos publicos) ou para outro motivo qualquer apanhar animal alheio, sendo com elle axado, ou convencido por meio de exame verbal perante o Juiz de paz, de assim aver praticado ser pelo mesmo Juiz castigado impondo-lhe a pena de dois a quatro mil reis de multa e de dois a quatro dias de prizão se o individuo for livres, e com a pena de vinte cinco assoites publicos, se for escravo. Curitiba, 24 de maio de $1829^{14}$.
\end{abstract}

A legitimação da alforria, no Brasil imperial, era feita pelo escrivão de paz da vila ou freguesia onde estava sendo efetuado o registro, através de documentos entitulados escripturas de liberdade* ou cartas de alforria. O escrivão de paz redigia uma via desta carta, que ficaria sob a posse do emancipado ou do seu ex-senhor, e transcrevia uma cópia da mesma para o Livro de Notas da vila ou freguesia. Estas cartas de liberdade eram conseguidas através de várias maneiras, como veremos adiante, e em função de motivos não menos variados. Mesmo nos casos das alforrias onerosas, não podemos considerar a obtenção da liberdade como sendo automática. Muitas vezes um fator condicionante, prorrogava ainda por algum tempo esta passagem de estatuto, como por exemplo a obrigação de servir o seu ex-senhor até a morte deste.

Lançamento de sua carta de liberdade que me foi aprezentada por Feliciano escravo que foi de D. Joana Francisca de Abreu como abaixo se declara Digo eu Dona Joana Francisca de Abreu que entre os bens que possuo he bem assim, hum escravo mulato de nome Feliciano deidade de catorze annos pouco mais ou menos filho de minha escrava Francisca, acuso escravo Feliciano de minha livre vontade e sem constrangimento de pessoas alguma confiro a liberdade de hoje em diante e para todo o sempre pelo preço e valor de Duzentos mil reis cuja quantia de 200\$000. receberei do Reverendo Vigario o Senhor Ponciano Jose de Araujo da datta de hoje a quatro annos, a prezente escriptura ficava sobredito escravo Feliciano gozando de plena liberdade, como se liberto nascece com a condição reinante de me acompanhar durante a minha vida, e depois de meo falecimento não tendo o dito liberto inda idade de vinte e sinco annos, acompanhar ao dito Reverendo

14 CURITIBA. Posturas Municipais. 1820 - 1860. PEREIRA, M. R. M. (org.) Monumenta. Curitiba : Editora Aos Quatro Ventos, verão de 1998. p. 26.

* Como esclarecimento ao leitor, gostaria de salientar que as palavras escritura, freguesia e vila, estão nas fontes primárias com a seguinte grafia: escriptura, freguezia e villa. 
libertante, Ihes completar a dita idade não podera antes disto tomar Estado algum sem concentimento do sobredito libertante [...] Freguezia da Palmeira, 19 de janeiro de $1836^{15}$.

O padrão utilizado pelo escrivão, na elaboração das cartas de alforria, foi instituído ainda no período colonial. Primeiramente, aparece a identificação do proprietário do escravo que estava sendo liberto, assim como a localização de sua propriedade. Em Palmeira/PR localidades como Quero-quero, Pugas, Papagaios Novos, etc, referem-se aos quarteirões nos quais a região foi dividida. Provavelmente a origem destes, esteja nas diversas sesmarias concedidas na região pelo poder régio português no início do século XVIII, conforme citado anteriormente.

A segunda do documento, destina-se a caracterizar essencialmente o escravo emancipado, trazendo-nos o seu nome, (que em algumas vezes vem acompanhado do sobrenome do seu ex-senhor), a cor de sua pele, a origem e a idade.* Num terceiro momento, a carta nos dá alguns indícios dos motivos que estavam levando o proprietário a conceder a liberdade, e a presença ou não de algum ônus para a obtenção da alforria. Nas cartas onerosas são indicados além do valor a ser pago, as condições para este pagamento e, por vezes, o pagante.

A última parte da escritura de liberdade, revela os nomes das testemunhas presentes no ato do registro do documento em cartório. Nesta parte, ainda encontram-se dia, mês e ano da outorga da alforria e do seu registro em cartório, além do nome do escrivão que a registrou. Quanto à questão destas datas, vale lembrar que houve casos em que foi constatada uma diferença de alguns dias entre a outorga da alforria ao escravo emancipado, e seu efetivo registro legal perante o escrivão.**

\section{O perfil do escravo alforriado em Palmeira/PR}

Na historiografia brasileira, a questão da predominância de um ou outro sexo entre os escravos alforriados tem um caráter polêmico, dada a discrepância de dados entre diversas regiões. Esta discordância alimentou interpretações contraditórias, uma vez que poderia indicar a preferência dos senhores de uma determinada região em libertar mais os cativos de um sexo em detrimento de outro. Nos estudos relativos à Bahia nos séculos XVII e XVIII de Schwartz ${ }^{16}$, e nos de Mattoso ${ }^{17}$ para os séculos XVIII e XIX, foi identificada uma predominância do sexo femi-

15 CURITIBA. Câmara Municipal . Livrro de Notas do Escrivão de Paz de Palmeira. 1834 à 1839. v. 03. Armazenado no Arquivo da Biblioteca da Câmara. Trecho de uma das escrituras de liberdade transcritas por Luís Henrique Novacki, em 1999.

* O estado civil do alforriado foi um dado que apareceu somente em três cartas de Palmeira/PR (1831-1848), a partir destes dados das fontes, podemos afirmar que havia uma certa parcela de escravos que eram casados. Outras fontes também confirmam este dado, como COSTA, I. N. da e GUTIÉRREZ, H. Nota sobre o casamento de escravos em São Paulo e no Paraná (1830). in: História: Questões e Debates, ano 5, n. ${ }^{\circ}$ 09, dezembro de 1984.

** O mesmo fenômeno foi observado por EISENBERG, P. L. Homens Esquecidos: escravos e trabalhadores livre no Brasil - séc. XVIII e XIX. Campinas : Editora da UNICAMP, 1989.

16 SCHWARTZ, S. B. A manumissão dos escravos no Brasil colonial - Bahia, 1684 - 1745. Anais de História, Assis, ano 6, p. 71-114, 1974.

17 MATTOSO, K. M. de Q. A propósito das cartas de alforria - Bahia, 1779 - 1850. Anais de História. Assis, ano 6, p. 23-52, 1972. 
nino da ordem de $66.9 \%$ e 61.6\%, respectivamente. Nas cartas de P. Eisenberg ${ }^{18}$, em Campinas a porcentagem de mulheres forras é da ordem de 51.9\%.

Quanto ao sexo dos escravos alforriados em Palmeira, entre 1831 e 1848, à partir da leitura das fontes podemos afirmar que, assim como nos estudos dos autores citados anteriormente, nesta região temos também um predomínio de mulheres entre os libertos. Uma semelhança que ganha relevo, por tratar-se de uma região com características econômicas diferentes em relação à Salvador, pois estava voltada para a criação de bovinos e eqüinos, além da invernagem de muares, para atender o mercado interno do Império ${ }^{19}$. As regiões da Bahia e de São Paulo, economicamente estavam voltadas para a agricultura de exportação.

Se observar-mos as fontes em termos numéricos, veremos que estas mulheres correspondiam a um total de 24 pessoas, que eqüivalem a $53.33 \%$ do total de 45 alforriados, conforme a Tabela 01. Esta maioria, deve ser considerada com a ressalva de se levar em consideração um outro aspecto, ou seja, o número total de emancipados.

Neste total, observamos que há uma presença significativa de homens no conjunto da população liberta de Palmeira, totalizando 21 indivíduos. No entanto, é necessário dizer que em virtude do número total de cartas ser relativamente baixo, uma única pessoa representa um percentual aproximado de $2.22 \%$, fazendo com que os resultados finais alterem-se consideravelmente numa análise dos percentuais. Devido a este fato, observando apenas os números absolutos, achamos que o mais correto seria dizer que no total de alforrias registradas em Palmeira no período enfocado encontramos um certo equilíbrio entre homens e mulheres, com um leve predomínio do sexo feminino.

TABELA 01

Distribuição de escravos alforriados por sexo (Palmeira: 1831-1848)

\begin{tabular}{|l|c|c|}
\hline \multicolumn{1}{|c|}{ Sexo } & Nos. absolutos & $\%$ \\
\hline Homens & 21 & 46,67 \\
\hline Mulheres & 24 & 53,33 \\
\hline Total & 45 & 100,00 \\
\hline
\end{tabular}

* Fonte: CURITIBA. Câmara Municipal . Livros de Notas do Escrivão de Paz de Palmeira. 1831 à 1848. Armazenados no Arquivo da Biblioteca da Câmara.

A idade dos libertos ou forros, é um dos dados que deve ser abordado com o máximo de cuidado num estudo sobre registros de liberdade, pelo fato da maioria das cartas trazerem este dado de maneira imprecisa, quando o trazem. Há também os casos, nos quais a idade é apresentada através das chamadas idades descritivas, que constituem-se na identificação do liberto como "mulatinho", "crioulinho", "moleque", "molecão", "meninota", etc. Sua utilização foi uma constante em regiões como a Bahia açucareira, e as plantações de café em Campinas, no decor-

18 EISENBERG, P. L. Idem.

19 PINHEIRO MACHADO, Brasil. Campos Gerais - Estruturas Agrárias , Curitiba : Editora da

UFPR, 1968. p.29-30. 
rer dos século XVII, XVIII e XIX20. Do mesmo modo, elas aparecem no primeiro planalto paranaense, como nos mostra Adriano Lima ${ }^{21}$.

Para a região de Palmeira, onde predominava a pecuária e a agricultura de subsistência, a situação não foi diferente. A documentação não menciona a idade de mais da metade dos libertos nesta freguesia, mais precisamente de 23 africanos e seus descendentes (51.11\%), sendo 08 homens e 15 mulheres. A idade dos 22 libertos que tiveram as suas idades anotadas pelo escrivão de paz nesta freguesia, na grande maioria das vezes era acrescida a expressão "para mais ou para menos", revelando-nos que este era um dado elaborado a partir da indicação feita pelo ex-senhor do emancipado e/ou da 'aparência' que o mesmo apresentava ao escrivão.

$\mathrm{Na}$ análise das faixas etárias mencionadas nas cartas de alforria, adotou-se a seguinte convenção: as pessoas que tivessem até 08 anos foram consideradas como muito jovens, as que estivessem entre 08 e 17 anos, como jovens, sendo que o termo mais apropriado poderia ser o de adolescentes. Conjuntamente, estes dois primeiros grupos atingiram aproximadamente $11 \%$ dos libertos, num total de 05 pessoas. No entanto, o mesmo pode chegar a 09 se considerarmos as escravas libertas na alforria coletiva denominadas como "filhas".

A seguir, temos a abrangente faixa etária dos adultos que, incluindo todos os indivíduos entre 18 e 50 anos, atingiu $28.89 \%$ dos alforriados, sendo que este número, mais do que o das outras faixas etárias em função das atividades da região e da alforria coletiva, pode ser ainda maior. Os adultos, sem dúvida alguma, correspondem à maioria dos libertos de Palmeira, entre 1831 e 1848. Por último, os emancipados descritos com uma idade acima desta última foram denominados de idosos, correspondendo à $8.89 \%$ do total.

Houve um certo equilíbrio em Palmeira, entre os idosos e as crianças/ adolescentes alforriados, pois para os primeiros temos um total de 04 , e para 0 outro grupo, 05 libertos. Se considerarmos que todas aquelas "filhas" citadas anteriormente tinham 08 anos ou menos, mesmo sendo uma especulação pois nunca saberemos ao certo, um fato bastante curioso seria constatado em Palmeira. Com base na Tabela 02, poderíamos dizer que para esta região no recorte temporal utilizado, não haveria nenhuma escrava liberta que estivesse na adolescência.

Em relação à anotação da idade dos escravos, a documentação de Palmeira guarda uma peculiaridade em relação às de outras regiões analisadas pela historiografia citada. Nos Livros de Notas do Escrivão de Paz de Palmeira, encontramos somente a descrição da idade acrescida da expressão "para mais ou para menos", ou a omissão pura e simples do dado. Em nenhuma carta de alforria, foram encontradas as idades descritivas ${ }^{22}$. Esse fato é ainda instigante se comparado à documentação analisada por Adriano Lima, que compreende uma localidade mais

20 MATTOSO, K. M. de Q. A propósito das cartas de alforria - Bahia, 1779 - 1850. Anais de História. Assis, ano 6, p. 23-52, 1972. EISENBERG, P. L. Homens Esquecidos: escravos e trabalhadores livre no Brasil - séc. XVIII e XIX. Campinas : Editora da UNICAMP, 1989.

21 LIMA, A. B. M. Sob as graças da liberdade: concessões de alforria na América Portuguesa, Curitiba (17901825). Curitiba : Monografia de Bacharelado - UFPR, 1998.

22 SCHWARTZ, S. B. A manumissão dos escravos no Brasil colonial - Bahia, 1684 - 1745. Anais de História, Assis, ano 6, p. 71-114, 1974.

76

Qevista Xernáculo 
próxima daquela em questão, na qual o uso de idades descritivas é freqüente ${ }^{23}$.

TABELA 02

Distribuição de escravos alforriados por idade, incluindo o sexo (Palmeira: 1831-1848)

\begin{tabular}{|l|c|c|c|c|c|}
\hline \multicolumn{1}{|c|}{ Denominação } & Faixa etária (anos) & Homens & Mulheres & Nos. absolutos & $\%$ \\
\hline Muito jovem & $0-8$ & 01 & 02 & 03 & 6.67 \\
\hline Jovem & $9-17$ & 02 & 00 & 02 & 4.44 \\
\hline Adulto & $18-50$ & 09 & 04 & 13 & 28.89 \\
\hline Idoso & +50 & 01 & 03 & 04 & 8.89 \\
\hline Não especificado & ---- & 08 & 15 & 23 & 51.11 \\
\hline Total & ---- & 21 & 24 & 45 & 100.00 \\
\hline
\end{tabular}

* Fonte: CURITIBA. Câmara Municipal . Livros de Notas do Escrivão de Paz de Palmeira. 1831 à 1848. Armazenados no Arquivo da Biblioteca da Câmara.

No que refere-se à cor e à procedência dos libertos, a maioria dos autores considera estes dois aspectos separadamente. Também o consideramos, estando cientes que referem-se a dados diferentes. No entanto, para o estudo das cartas de alforria ou de liberdade de Palmeira, os mesmos serão abordados numa única tabela em detrimento da própria maneira como eles surgem nas fontes.

A opção por esta forma conjunta de análise, ocorreu em função de que em algumas cartas aparecem somente o indicativo da cor do liberto ("mulato"), em outras apenas o da origem do mesmo ("crioulo" ou "nação"), e ainda num outro conjunto de cartas temos a indicação dos dois aspectos para o mesmo indivíduo ("crioulo, mulato"). Este fato, nos fez chegar à conclusão de que uma análise isolada de ambos não seria muito proveitosa, uma vez que teríamos um número ainda mais elevado de dados não especificados. Mesmo agindo desta forma, foi considerável o número de escrituras de liberdade que não trazem nenhuma das duas informações, atingindo a marca de $37.77 \%$, ou seja, 17 cartas de um total de 33 .

Nas cartas em que um ou ambos os dados aparecem, foi identificada uma grande maioria da ocorrência do termo "mulato" entre os emancipados dos sexos masculino e feminino, no que refere-se à cor destes indivíduos. Esta predominância prevalece mesmo se forem considerados como "pretos" todos os emancipados denominados como sendo de "nação".

Quanto a procedência destes libertos de Palmeira, mesmo sendo uma unanimidade entre os estudiosos da escravidão paranaense, de que a maioria dos escravos desta Comarca eram crioulos ou indivíduos nascidos no Brasil, os números absolutos mostram-nos que os emancipados "crioulos" e os de "nação" tiveram exatamente o mesmo percentual de $13.33 \%$. Porém, há a possibilidade desta eqüidade tender para os primeiros, em virtude da quantidade de cartas nas quais este dado não aparece.

Outro fato que não pode deixar de ser mencionado, é que nas cartas de 
alforria em questão em nenhuma vez apareceu o termo "pardo", como sendo indicativo da cor destes emancipados, como apresentam-nos alguns autores ${ }^{24}$. Também não apareceu em nenhuma das cartas referentes aos africanos, a indicação dos seus locais de embarque, como no estudo de Adriano Lima.

TABELA 03

Distribuição de escravos alforriados por cor e procedência, incluindo o sexo (Palmeira: 1831-1848)

\begin{tabular}{|l|c|c|c|}
\hline Cor e procedência & Homens & Mulheres & $\%$ \\
\hline Mulato & 09 & 04 & 28.89 \\
\hline Crioulo & 02 & 04 & 13.33 \\
\hline Nação & 04 & 02 & 13.33 \\
\hline Crioulo Mulato & 02 & 01 & 6.68 \\
\hline Não especificado & 04 & 13 & 37.77 \\
\hline Total & 21 & 24 & 100.00 \\
\hline
\end{tabular}

* Fonte: CURITIBA. Câmara Municipal . Livros de Notas do Escrivão de Paz de Palmeira. 1831 à 1848. Armazenados no Arquivo da Biblioteca da Câmara.

A modalidade ou forma pela qual os escravos eram alforriados na região enfocada, juntamente com os dados referentes ao sexo destas pessoas, aparecemnos como os únicos aspectos constantes em todas as escrituras, sem exceção. Isto vem a possibilitar uma análise bastante aproximada da realidade deste local, entre 1831 e 1848. Como o próprio nome já nos indica, esta informação apresenta o modo pelo qual o senhor estava concedendo a liberdade ao escravo. Para efeitos de análise, dividimos as cartas de alforria de Palmeira em dois grupos distintos. As escrituras nas quais houve o pagamento de algum valor em moeda corrente (réis) ou em algum outro bem material, foram consideradas como onerosas, e as cartas concedidas sem o pagamento do referido valor, foram caracterizadas como gratuitas. Em ambos os casos, temos algumas situações nas quais o escravo 'liberto' via-se atingido por alguma condição que contraditava o seu novo estatuto social de homem livre. O fator condicionante que mais apareceu na documentação, foi o de "acompanhar o seu senhor até a morte do mesmo".

Entre as "moedas" com as quais os escravos pagavam suas liberdades, temos o caso do escravo Francisco, 38 anos, mulato, liberto pela senhora Maria dos Passos em 1843. Entregou à mesma "04 bois carreiros e sua mula" num total de 96\#000 (noventa e seis mil réis), restando ainda 160\#000 que seriam pagos a ela ou a seus herdeiros, o que indica que havia a possibilidade de um pagamento à prazo da quantia ${ }^{25}$. Outra 'moeda' utilizada como forma de pagamento da alforria, consistia na entrega ao senhor de um outro escravo, como sendo uma parcela do

24 PILATTI BALHANA, A.; PINHEIRO MACHADO, B.; WESTPHALEN, C. História do Paraná, Curitiba : Editora Grafipar, 1968.

25 CURITIBA. Câmara Municipal . Livro de Notas do Escrivão de Paz de Palmeira. 1839 à 1844. v. 04. fl. 57 no verso. Armazenado no Arquivo da Biblioteca da Câmara. 
preço justo. Quanto a esta modalidade, encontramos apenas o caso do escravo Manoel, de "trinta e tantos anos", mulato, liberto pelo senhor Francisco João Baptista após entregar-Ihe "150\#000 em moeda corrente, além de 1 escravo de Nação"26.

Confrontando as modalidades onerosas e gratuitas para a concessão da liberdade, constatamos uma relativa maioria de alforrias concedidas gratuitamente, chegando a um total de $73.34 \%$ das cartas, contemplando 33 emancipados. No entanto, não devemos nos esquecer de que neste total, temos 17 libertos presos a uma condição, o que nos indica que houve apenas a ausência do ônus financeiro. As escrituras de liberdade onerosas, corresponderam à 14 libertos (26.66\%), sendo que destes, dois indivíduos (4.44\%) foram 'agraciados' com a condição mais usual pelos senhores rurais de Palmeira de acompanhar o seu ex-senhor até a morte deste, além do pagamento estipulado, conforme a Tabela 03.

Contudo, estas modalidades apresentam-se mais claramente quando são analisadas em conjunto com o sexo destes libertos. De um total de doze emancipações onerosas, incluindo seu sub-ítem, temos um total de 10 homens para 02 mulheres nesta categoria. Analisando agora as cartas concedidas gratuitamente, apesar do fator condicionante, temos 33 emancipados, sendo que destes 22 são do sexo feminino e 11 do masculino. Evidentemente a generalização, aqui como em qualquer outro caso, não cabe. No entanto, poderíamos dizer que na maioria das vezes em Palmeira os homens pagavam pela sua liberdade e as mulheres não.

\section{TABELA 04}

Distribuição de escravos alforriados por modalidade, incluindo o sexo (Palmeira: 1831-1848)

\begin{tabular}{|l|c|c|c|}
\hline \multicolumn{1}{|c|}{ Modalidade } & Homens & Mulheres & $\%$ \\
\hline Onerosa & 08 & 02 & 22.22 \\
\hline Onerosa cl condição & 02 & 00 & 4.44 \\
\hline Gratuita & 06 & 10 & 35.56 \\
\hline Gratuita c/ condição & 05 & 12 & 37.78 \\
\hline Total & 21 & 24 & 100.00 \\
\hline
\end{tabular}

* Fonte: CURITIBA. Câmara Municipal . Livros de Notas do Escrivão de Paz de Palmeira. 1831 à 1848. Armazenados no Arquivo da Biblioteca da Câmara.

Quanto aos motivos que propiciaram a alforria aos escravos, muitos autores nos mostram que a mais freqüente expressão utilizada nas cartas foi "bons serviços prestados" ou alguma outra análoga. Nas alforrias de Palmeira, entre 1831 e 1848, esta expressão também aparece com bastante freqüência. Todavia, não pudemos comprovar que este era o real motivo pelo qual o senhor estava concedendo a liberdade a seu escravo. Entendemos que estes termos não indicam, necessariamente, uma 'gratidão' por parte do senhor, pois na documentação analisada ele aparece indistintamente tanto nas alforrias gratuitas como nas onerosas.

26 CURITIBA. Câmara Municipal . Livro de Notas do Escrivão de Paz de Palmeira. 1831 à 1834. v. 01. fl. 48 frente e verso. Armazenado no Arquivo da Biblioteca da Câmara. 
Isto nos faz supor que, este fosse mais um dos elementos constituintes do modelo, utilizado pelo escrivão de paz, para o registro da outorga da liberdade. Somente nas escrituras de dois indivíduos libertos, pudemos constatar um motivo plausível para a concessão da liberdade. Os escravos Francisco (de Nação) e Luís ${ }^{27}$, foram libertados pelo testamenteiro de seu proprietário, em virtude da morte do mesmo. Provavelmente suas liberdades foram outorgadas ainda quando o senhor estava vivo, com a condição de ser efetuado o registro das mesmas, quando o senhor morresse.

\section{Uma singularidade em Palmeira}

A alforria coletiva, ou seja, o registro da concessão da liberdade a dois ou mais escravos numa única carta de alforria, foi algo constante nas fontes analisadas pela historiografia em questão. No entanto, na leitura de todas as cartas de alforria contidas nos Livros de Notas do Escrivão de Paz de Palmeira/PR, para o período abordado, encontramos apenas um caso, ocorrido exatamente no ano de 1848. Neste documento, a senhora Clara Magdalena dos Santos concede gratuitamente a liberdade à doze escravos que a ela pertenciam, porém com a condição de que estes deveriam acompanhá-la até a sua morte.

Pudemos constatar que houve uma certa confusão quanto ao início deste documento, pois no Livro de Notas, o mesmo inicia contendo o nome de alguns escravos e excetuando o de outros, de uma forma tão confusa para o escrivão que num determinado momento o mesmo decide reiniciar a escritura, colocando a expressão "sem efeito". Na transcrição apresentada na íntegra nesta análise, esta parte não foi incluída. Esta confusão durante a redação da escritura, mostra-nos que a senhora Clara Magdalena dos Santos possuía um número total de escravos maior do que aqueles que estavam sendo libertos, ou seja, esta senhora estava entre os senhores que mais possuíam escravos em Palmeira. Mas vamos então ao que nos revela a fonte primária:

\footnotetext{
Escriptura de liberdade que fas Dona Clara Magdalena dos Santos a seos escravos, e escravas, de nomes Joaquina mullata, com suas filhas Sezarina e Quitéria, alem destas Claudina e sua filha Maria da Glória, assim Ilena, Maria Eufrazia, Rita, Benedita e sua filha Maria, Bento e Adão como abaixo se declara.

Saibão quantos este publico instrumento de escriptura de liberdade virem que sendo no anno do nassimento de nosso Senhor Jesus Cristo demil oito centos e quarenta e oito, aos vinte e sete dias do mês de setembro do dito anno nesta paragem denuminado Pugas destrito da freguezia da Palmeira, Termo da cidade de Coritiba, quinta comarca da Província de São Paulo; nas casas de residecia de Donna Clara Magdalena dos Santos, onde fui vindo eu Escrivão de Paz e Nottas ao diante nomeado e sendo ahi presente Donna Clara Magdalena dos Santos, aqual reconheço pella própria e dou fé, e por ella me foi dito perante as testemunhas abaixo nomeadas e asignadas, que héra Senhora elegítima possuidora de humas escravas mullatas e pretas, e bem assim hum escravo de nassão, e hum mullato, de nomes, Joaquina, Quitéria, Sezarina, Claudina, Maria da Glória, Ilena, Maria Eufrázia, Rita, Benedita e Maria filha, Bento de nassão e Adão mulato. Cujos escravos já mencionados muito de sua livre vontade e sem constrangimento algum Vinha por esta Ihes seder a liberdade perpétua em geral atodos pellos bons servissos eumildades com
}

27 CURITIBA. Câmara Municipal . Livro de Notas do Escrivão de Paz de Palmeira. 1831 à 1834. v. 01. fls. 46 frente e verso, 48 frente e verso. Armazenado no Arquivo da Biblioteca da Câmara. 
que athé o presente Ihe tenhão servido, sem onos de pagamentos alguns por isso que de hora em diante poderão possuir e desfrutarem do gozo de liberdade como cousa q' focem nassidos de ventres livres, e sede alisi (?) todo senhorio Jus e duminio que tinha em ditos escravos; Só sim com a condição de servirem aoltorganta Donna Clara Magdalena dos Santos, durante sua vida, como athé aqui tenhão servido e por fallecimento delia poderão cada hum tratarem de suas vida como libertos que ficão sendo, Cujas liberdades Ihes da já pello amor de Deos, e da criação que Ihes tem dado ebao (?) serviços que delles têm tido, e por isso pede a todas as Justissas Imperial que haja de cuprir e guardar esta Escriptura de liberdades em juiso aufóra (?) delles, não revogando enem reclamando emtempo algum; alguem que possa seabilitar por erdeiro por morte sua, Só sim Ihe ficando odireito para si somentes de revogar e reclamar contra qualquer dos libertos que Ihidem causa, alias disso sempre sera firme e valioza. E decomo assim o disse aoltorgante me pedio este Instrumento que sendo-lhes lido por achar conforme asignou por ella a seo rogo por não saber escrever, o Capitão Francisco de Paula Faria, com as testemunhas Antonio Jozé de Lima, Manoel Onório de Siqueira, e Joaquim Ivo de Andrade; todos demim reconhecidos e dou fé. E Eu Jozé Bernardes Ribeiro e Silva, escrivão que o escrevi. ${ }^{28}$

$\mathrm{Na}$ passagem do documento onde encontramos "a liberdade perpétua em geral atodos pellos bons servissos eumildades com que athé o presente the tenhão servido", talvez esteja o provável motivo que estaria levando à concessão desta benesse. Quais os motivos que estariam levando esta rica senhora analfabeta, e que não possuía herdeiros, a tomar tal atitude? Sydnei Chaloub ${ }^{29}$, afirma que havia uma série de expectativas, por parte dos senhores quando alforriavam seus escravo, no que se refere ao comportamento dos mesmos. Creio, segundo as informações da fonte, que a carta em questão não estaria sendo registrada com o intuito de 'amansar' estes cativos, pois aos mesmos foi atribuída a característica da humildade, bastante típica da submissão inconteste. No entanto, a possibilidade de melhorar o comportamento dos escravos é uma hipótese que apresenta-se e não deve ser desconsiderada.

\section{Conclusão}

Com relação ao sexo destes alforriados, foi identificado um certo equilíbrio entre ambos, com um leve predomínio feminino. A maioria dos estudos também apontaram para uma maioria de mulheres, entre os libertos. Kátia Mattoso ${ }^{30}$ e Peter Eisenberg ${ }^{31}$, atribuem esta tendência pelo fato das mulheres terem uma menor produtividade e um valor de mercado inferior ao dos homens, além da questão dos laços afetivos destas com os seus senhores. Apenas o trabalho de Adriano Lima $^{32}$, apontou para uma leve predominância de homens entre os escravos libertos. Acredito que para Palmeira/PR, o primeiro argumento não seja possível de ser atribuído, pois o mesmo só faria sentido se o senhor vendesse sua escrava por

28 CURITIBA. Câmara Municipal . Livro de Notas do Escrivão de Paz de Palmeira. 1847 à 1849. Armazenado no Arquivo da Biblioteca da Câmara. v. 8, fls. 29 verso e 30 frente.

29 CHALOUB, S. Visões da liberdade: Senhores, escravos e abolicionistas da corte nas últimas décadas da escravidão in: História: Questões e Debates. Curitiba, ano 9, n. 16, p. 5 - 37, 1988.

30 MATTOSO, K. M. de Q. A propósito das cartas de alforria - Bahia, 1779 - 1850. Anais de História. Assis, ano 6, p. 40, 1972.

31 EISENBERG, P. L. Homens Esquecidos: escravos e trabalhadores livre no Brasil - séc. XVIII e XIX. Campinas : Editora da UNICAMP, p. 96, 1989.

32 LIMA, A. B. M. Sob as graças da liberdade: concessões de alforria na América Portuguesa, Curitiba (17901825). Curitiba : Monografia de Bacharelado - UFPR, 1998. 
um determinado valor com o intuito de recuperar o capital empatado. No caso paranaense, como já vimos, a maioria das escravas libertas o foram de maneira gratuita, vindo a contrariar a lógica capitalista do argumento destes autores. É possível também, para o nosso caso, a hipótese levantada por P. Eisenberg, que coloca a família escrava como sendo a principal responsável por este predomínio feminino, pois qualquer criança gerada teria o mesmo estatuto social do ventre de sua mãe.

No aspecto referente à idade, mesmo atentando para a dificuldade deste dado, encontramos uma grande maioria de emancipados adultos, ou seja, de indivíduos que possuíam entre 18 e 50 anos no ato do registro da escritura. Dos autores citados, o único que encontrou um padrão ou perfil diferente do identificado em Palmeira/PR foi P. Eisenberg, que encontrou uma predominância de indivíduos muito jovens e muito velhos entre os emancipados. Segundo o autor, isso revela o baixo valor de mercado de ambos, dos primeiros em função da alta mortalidade infantil, e dos outros pela baixa produtividade. Acreditamos que o fato de um grande número de adultos emancipados, mulheres e homens, indivíduos que estariam no ápice de suas produtividades, está diretamente relacionado com as características inerentes à pecuária. Este modo de trabalho, propicia relações mais "frouxas" entre senhores e escravos que noutras atividades agrícolas.

Quanto à cor e à procedência dos escravos alforriados, constatamos que a presença em massa de mulatos e de crioulos, está diretamente relacionada ao atuante comércio interprovincial de escravos no século XIX, fazendo com que a maioria dos escravos dos Campos Gerais fosse proveniente daquela ou de outras regiões da Província. Este comércio, ocorreu em virtude de muitos fazendeiros da região serem provenientes de São Paulo, Santos e Paranaguáa3, e estarem constantemente redistribuindo suas "peças" nas várias propriedades.

Na modalidade da concessão das cartas de liberdade em Palmeira/PR, constatamos uma predominância absoluta das alforrias gratuitas, embora mais da metade destes casos tivessem a cláusula restritiva de "acompanhar o senhor até a morte deste", o que vem a questionar a validade do ato. Para P. Eisenberg, por exemplo, este tipo de concessão somente era feita aos escravos improdutivos das plantações de café, em

Campinas. Essa afirmação, confirma ainda mais o caráter diferenciado das relações escravistas na pecuária, que no nosso estudo foi desenvolvida em conjunto com a agricultura de subsistência.

Existe um aspecto que é de fundamental importância, e que não podemos deixar de mencioná-lo. Sidney Chaloub, num artigo publicado em $1988^{34}$, analisando um período posterior ao estudado nesta monografia, cita-nos um fato que raramente acontecia com os escravos, mas que era uma prática legalmente aceita, ou seja, a revogação da alforria concedida, por ingratidão. Disse raramente, porque nas 2.093 cartas analisadas por Peter Eisenberg em Campinas foram identificados apenas dois casos, e Robert Sienes encontrou um único exemplar desta para Sorocaba. Segundo Chaloub, a anulação da alforria por ingratidão "estava prevista no título LXIII do Livro IV das Ordenações Filipinas" ${ }^{35}$, sendo considerado ingrato 
aquele que agredisse verbalmente ou fisicamente o seu ex-senhor, prejudicasse sua fazenda ou não ajudasse o mesmo em caso de fome ou necessidade. Este tipo de anulação, veio a ser cancelado somente em 1871, estando em plena vigência na primeira metade do século XIX. Na análise das cartas de alforria de Palmeira/ PR, não houve nenhum caso de revogação da mesma por ingratidão, levando-nos a crer que os libertos desta localidade não agiram de maneira ingrata contra seus senhores, ou assim agiram, e os mesmos não tiveram a coragem suficiente para revogar a concessão da liberdade.

As conclusões históricas de uma determinada sociedade, situam-se no campo das hipóteses e das possibilidades, destruindo a concepção da verdade única e suprema, e abrindo caminho para as "várias verdades" possíveis de terem acontecido. $\mathrm{Na}$ análise do perfil dos escravos alforriados em Palmeira/PR, entre 1831 e 1848, encontramos características diferenciadas daquelas identificadas pela historiografia para outras regiões do país, como a faixa etária dos libertos e a ausência de ônus na obtenção da alforria de ambos os sexos, dentre outros. Possivelmente, estas particularidades estejam vinculadas às relações menos rígidas, mas nem por isso humanas, existentes entre senhores e escravos na pecuária. Uma atividade que caracterizou-se no Paraná do século XIX, pelo modo extensivo na criação do gado, fazendo com que o escravo-peão tivesse uma alta mobilidade territorial e possuísse uma maior confiabilidade por parte do seu senhor. Ou seja, através dos registros de liberdade é possível identificarmos uma relação diferenciada entre senhores e escravos nesta localidade paranaense, em comparação àquela ocorrida na monocultura da cana-de-açúcar ou nos diversos núcleos urbanos.

Embora esta não seja a intenção da maioria das autoridades governamentais, que o enevoado mundo da escravidão no Paraná, assim como o da cultura dos africanos e seus descendentes, desperte cada vez mais estudos nestas áreas, ajudando as sociedades contemporâneas na construção da identidade da cultura afro-paranaense, muitas vezes sufocada por ideologias hipócritas como o "mito do Paraná branco ou dos imigrantes".

\section{BIBLIOGRAFIA}

CALDEIRA, J. et al. Viagem pela História do Brasil. São Paulo : Companhia das Letras, 1997.

CHALOUB, S. Visões da liberdade: Senhores, escravos e abolicionistas da corte nas últimas décadas da escravidão in: História: Questões e Debates. Curitiba, ano 9, n. 16, p. 5 - 37, 1988.

COSTA, I, N. da; GUTIERREZ, H. Nota sobre o casamento de escravos em São Paulo e no Paraná (1830). in: História: Questões e Debates, ano 5, n. ${ }^{\circ} 09$, dezembro de 1984.

DEAN, W. Rio Claro: Um Sistema Brasileiro de Grande Lavoura 1820 -1920. Trad. Waldívia Portinho. Rio de Janeiro : Editora Paz e Terra, 1977.

EISENBERG, P. L. Homens Esquecidos: escravos e trabalhadores livre no Brasil séc. XVIII e XIX. Campinas : Editora da UNICAMP, 1989.

FERRARINI, S. A Escravidão Negra na Província do Paraná. Curitiba : Ed. Lítero- 
Técnica, 1971.

FLORENTINO, M. G. Em Costas Negras. São Paulo : Companhia das Letras, 1997.

FRANCO, M. S. de C. Homens Livres na Ordem Escravocrata. 4a edição. São Paulo : Editora UNESP, 1997.

FREiTAS, A. de. Palmeira. Reminiscências e Tradições, vol. II. Curitiba : Editora Lítero -Técnica, 1984.

GORENDER. J. O escravismo colonial. São Paulo : Editora Ática, 1985.

GUTIERREZ, H. Crioulos e africanos no Paraná (1798 - 1830). In: "Revista Brasileira de História", v. 8, n. ${ }^{\circ}$ 16, março-agosto, 1988.

IANNI, O. As Metamorfoses do escravo. São Paulo : Difusão Européia do Livro, 1962.

JOHNSON, L. L. Manumission in Colonial Buenos Aires (1776 - 1810). Hispanic American Historical Review. v.59, n.2, p. 258-279, 1979.

KOSTER, H. Viagens ao Nordeste do Brasil. São Paulo : Companhia Editora Nacional, 1942.

LIMA, A. B. M. Sob as graças da liberdade: concessões de alforria na América Portuguesa, Curitiba (1790-1825). Curitiba : Monografia de Bacharelado na UFPR. 1998.

MATTOSO, K. M. de Q. A propósito das cartas de alforria - Bahia, 1779 - 1850. Anais de História. Assis, ano 6, p. 23-52, 1972.

MATTOSO, K. M. de Q. Ser escravo no Brasil. São Paulo : Editora Brasiliense, 1982.

PEREIRA, M. R. de M. Semeando iras rumo ao progresso. Curitiba : Editora da UFPR, 1996.

PEREIRA, M. R. de M. Monumenta - Posturas Municipais de Curitiba, Ponta Grossa, Castro nas Décadas de 1820 a 1860. Curitiba : Editora Aos Quatro Ventos, 1998.

PILATTI BALHANA, A.; PINHEIRO MACHADO, B.; WESTPHALEN, C. História do Paraná , Curitiba : Editora Grafipar, 1968.

PILATTI BALHANA, A.; WESTPHALEN, C. Paraná 1822. Boletim n. 19 do Departamento de História da UFPR. Curitiba : Gráfica Vicentina, 1972.

PINHEIRO MACHADO, B. Campos Gerais - Estruturas Agrárias, Curitiba : Editora da UFPR, 1968.

PRADO JÚNIOR, C. História Econômica do Brasil. 3a edição. São Paulo : Editora Brasiliense, 1953.

SAINT-HILAIRE, A. de. Viagem à Curitiba e Santa Catarina. São Paulo : Editora da USP : Editora Itatiaia, 1978.

SCHWARTZ, S. B. A manumissão dos escravos no Brasil colonial - Bahia, 1684 1745. Anais de História. Assis, ano 6, p. 71-114, 1974. 